\title{
PREFACE: WILD TONGUES/Lenguas Necias
}

My family, as many Mexican families do, has always enjoyed a good laugh; even in the midst of difficult situations, or perhaps because of them, we have managed to amuse each other. Sometimes we laugh out loud, a carcajadas, until our stomachs or cheeks hurt; other times, we enjoy a good riddle or a chiste that elicits a smile. My mother, Carmen Ruiz Abril, who usually appeared to everyone as too serious and quick-tempered, had a loud laugh whenever my tía Rita, her youngest and only sister out of six siblings, would joke around with her. Mom loved music, and it was no mystery why she married my father, Jesús Urquijo Chávez, since he played two types of guitar-classic and requinto-really well. There were eleven children (three boys, eight girls) in my family back in 1980. At that point I was the third youngest and one of my father's favorites. He died when I was about to turn nine years old, but I remember his profound knowledge of jokes and music. On Sunday afternoons Dad would sit most of his children down around him to enjoy the music from his guitar. Since he could not sing and could not remember lyrics as well as he could remember the music, I was usually the one he would ask to sing a song while he played. Of course, I would oblige con gusto, as I felt very special to have him entrust me with such a big task. My memory, as it relates to music, has always been excellent, and I would not disappoint him as he played song after song and I sang each one from beginning to end. "Gema," a beautiful bolero, was one of our favorite songs. He and I also knew that Mom loved "Gema," so we would dedicate it to her often.

When my mom and dad got married, our paternal grandmother, Dolores Chávez, gave them two adobe rooms that she separated from her home by planting a few tall plants for a little bit of privacy. My dad was a maestro de obras, and he could design and construct any structure, from a simple house to a mansion; however, he only managed to build three walls that he attached to the old adobe structure-never finishing the addition that was supposed to be a large room. Instead, the two adobe rooms had to be multipurpose: one was a kitchen by day and my parents' bedroom by night as they 
slept on the floor, and the other functioned as a bedroom, a living room, a sewing room, and a TV room all at once. It was in this second room where I remember sitting in front of our black-and-white TV watching Cantinflas, Tin Tan, La Willy, and other actors in classic Mexican movies, where I was first introduced to many of the characters covered in Wild Tongues: Transnational Mexican Popular Culture. Often, my siblings and I would sit together, fighting for space on the only bed in the room, to watch these films. I remember everyone laughing at the slapstick comedy and linguistic maneuvers that these comedians would present. Our small television set had lost its main plastic dial, and every time we needed to change the channel we would get a small electric shock when we touched it. When the films were getting boring, which meant less slapstick and more talking, inevitably one of my older brothers would touch the TV button. Then he would shock everybody, as we would usually sit in close proximity to each other. The fun would continue for a few minutes by having everyone form a line to be shocked. There was never a dull moment at home. How could there be with so many intelligent, mischievous children who had to be entertained? Little did I know that I would be storing memories that would surface and provide me with fodder for my scholarly pursuits.

When my dad died at a young age, Mom was forced to raise us by herself. With him no longer around, I was forced to defend and protect myself and my two younger sisters from the older brothers, who would bully and push us around. I was small in age and stature, so I mostly had to defend myself verbally; this is where my "Wild Tongue" comes in. My middle name became "hocicona/loudmouth" as well as "marimacha/tomboy," as I would not desist in my oral defense and tough attitude against familial injustices. Since Mom was not around because of her long hours at work in other people's homes, she insisted that I had to learn to defend and protect myself from anyone. I learned from the best. My mom did not suffer fools well, and she became my role model of a powerful woman who would stand up for herself. But somehow, as hard as she worked, our family was barely sustaining itself financially. Therefore, in order to help her in this enormous task, at sixteen I left home in Hermosillo, Sonora, for Los Angeles, California, where I was to attend high school, learn English, and return to Mexico to become a bilingual secretary. Nobody in my family had finished high school, but I believed I could do it. And I did. But I also finished a bachelor's, a master's, and a doctorate degree along the way. In graduate school, when I had to select a dissertation topic, it seemed only fitting that I would write about a subject that would allow me to connect my two cultural experiences: as a Mexicana and as a Chicana. My aim in Wild Tongues is to 
bridge the cultural productions in both countries by Mexican and Chicana/ Chicano artists in order to explore how national boundaries and nationalist narratives define and constrict notions of identity.

My exploration of blurring the cultural borders artificially constructed and constricting began when I was an undergraduate student and saw a clear connection between my two separate and disparate lives on each side of the border. At the University of California, Riverside (UCR) the cultural programmers at Chicano Student Programs organized the visit of several artists each year. The most special visit to me was when Lalo Guerrero came to our campus and filled up the main auditorium. I had heard of Guerrero only as the singer of the ardillitas (his version of the Chipmunks) when I was growing up in Mexico. To my surprise, I found out that there were many types of music that he had composed: from his parodies to his pachucada songs. My interest in connecting the two aspects of my life spent in each country was sparked at this concert.

Later on, Chicano Student Programs at UCR also invited artists and writers like María Elena Gaitán, Cherríe Moraga, Luis Alfaro, and Mónica Palacios, among several others, who would eventually become part of my graduate studies research. Wild Tongues allows me to analyze Mexican and Chicana and Chicano cultural productions, which have traditionally been studied separately, in order to theorize the role of popular culture in both the United States and Mexico. It is one of the few books that analyzes Mexican and Chicana/Chicano popular culture through a transnational lens.

Wild Tongues argues that the cultural production of and about people of Mexican descent in the United States cannot be seen in isolation from the cultural production of Mexico. To account for this interrelatedness, a comparatist, historically grounded approach is necessary. My study offers a way of re-imagining the limitations of nation-centered thinking and reading. These analyses also reveal the ways in which cultural productions mutually influence the United States and Mexico because they are a product of transnational capitalism. For example, the figures of the peladita and the peladito (down-trodden, destitute, comic figure) and the pachuca and the pachuco (Mexican zoot-suiters) are connected across the border. In Wild Tongues, I discern these transnational connectivities by tracing their configuration in a variety of cultural productions including literature, theater, film, music, and performance art. The concept of transnationalism derives from a transnational capitalist socioeconomic milieu that exists on the border in these transnational sites.

These four figures symbolize the destitute and/or working classes in both countries; they represent anti-establishment and dissenting voices. 
In the Mexican historical context, especially during the I920s, the peladita and the peladito become stock characters who, as social critics, comment upon certain aspects and political decisions of the Mexican government. In the United States, the pachuca and the pachuco also represent an antiestablishment and marginalized figure during the r940s. In Wild Tongues I use archival research and oral histories to recover, reconnect, and reinscribe these comedic and theatrical figures in Chicana/Chicano and Mexican cultural studies. Until recently, these fields of study have traditionally privileged the male figures of the peladito and the pachuco. My study reinscribes the peladita and the pachuca, the female versions of the destitute working class and their contributions to the genre.

To understand the cultural productions in which these are central figures, it is necessary to situate them in a historical, social, and economic context. Throughout the twentieth century the United States and Mexico have depended on each other economically, especially in the arena of cheap labor, where the latter has constantly supplied the former. This dependency has existed under conditions of economic exploitation in which workers of Mexican descent are constructed as classed and racialized subjects. Nevertheless, comedians and other social critics have denounced and resisted the exploitation and reification of Mexican laboring bodies through cultural productions that display the four figures this project analyzes.

Wild Tongues is divided into five chapters; each one examines a particular figure through a different cultural production. A main focus of the analysis of each chapter is language use. Each of the four figures uses the language of the working class, in which Spanish and English are sometimes combined through code-switching, depending on the need to communicate a particular idea. In addition, the pachuca and the pachuco use Caló, a language particular to them. Moreover, a specific way of dressing sets them apart from the rest of the working-class community.

Chapter I examines the character of the peladito in Daniel Venegas's novel Las aventuras de Don Chipote, o Cuando los pericos mamen (I928), translated as The Adventures of Don Chipote, or, When Parrots Breast-Feed, and analyzes its emergence and transformations while it situates its origin specifically within teatro de carpa (tent theater) on both sides of the border. This figure is generally seen as a comedic and naive character that highlights the exploitation of the working class. In this novel in particular, the peladito calls attention to the brutalized and exploited body of the undocumented Mexican laborer during the I920s; he is presented in a constant state of hunger and sleep deprivation. To highlight and analyze the functions and transformations of the character through the physical body, Mikhail 
Bakhtin's theory of the carnivalesque is especially useful because I seek to present the grotesque reification of the characters.

In chapter 2 I analyze the work of a Mexican peladita, Amelia Wilhelmy ("La Willy"), and a Chicana peladita, Beatriz Escalona ("La Chata Noloesca”, within the context of teatro de carpa and rasquachi humor. In Mexico, La Willy was famous for portraying a character called "El soldado Juan Marihuano," cross-dressing as a male revolutionary soldier who criticizes the government and the failed Mexican Revolution. In San Antonio, Texas, La Chata owned her theater company (Atracciones Noloesca) and traveled the southwestern United States, New York, and Cuba portraying the peladita in her comedy acts. Both comediennes survived technological advances that eradicated most carpas after World War II. Traditionally, Chicana/ Chicano cultural studies have privileged the figure of the male peladito, especially in the works of E1 Teatro Campesino. This chapter reinscribes both the Mexican and the Chicana peladitas in order to acknowledge their legacy, as well as the binational and reciprocal influences of these characters, who offer alternatives to male-centered traditional studies and highlight the connections between comedy, gender, sexuality, and rebelliousness. To date, very little is written on Wilhelmy, and what exists examines her only in very general terms among other male Mexican comedians. On the other hand, for Noloesca we have a few works by Chicana/Chicano scholars who have analyzed her from gendered perspectives.

The next chapter examines the connections between and reciprocal influences of the cultural representations of the figures of the pachuco on both sides of the border through the music of the post-World War II era-particularly that of composer and singer Lalo Guerrero. The main texts are a play and film entitled Zoot Suit by the Chicano playwright and director Luis Valdez and the film El bijo desobediente, in which Mexican comedian Germán Valdés (as “Tin Tan”) presents his Mexican pachuco. After I situate the characters historically and culturally within the framework of a subculture, I examine their representations in each text. Germán Valdés's pachuco is represented through the comedic point of view, while Luis Valdez represents him as a rebellious figure who can never be considered laughable. Nevertheless, the mutual influences on the representations of this figure on both sides of the border must be recognized. The main theoretical framework informing this chapter is the idea of the power of resistance and rebelliousness that a subculture and its young participants deploy to reclaim their laboring and exploited bodies.

Chapter 4 examines the pachuca/chola and the connection to all four characters in the work of María Elena Gaitán. The figures "Sufrida del Pue- 
blo" (also known as the "Chola with Cello") and "Connie Chancla" are the protagonists of two performance-art pieces created by this Chicana artist and activist during the I99os. Her work offers a feminist critique of the economic exploitation and physical brutalization of working-class people of Mexican descent in the United States. Gaitán's characters carefully blend the language and defiant attitude, among other characteristics, of the peladita and pachuca's cultural offspring, the chola, thus expanding a long genealogy of these figures. The characters are situated within a contemporary Chicana feminist framework and represent strong female figures who occupy public spaces previously unavailable to them. Informing these characters are the theories of Chicana critics Tey Diana Rebolledo and Yolanda Broyles-González about strong public female figures who go against the norms by denouncing their spatial and linguistic restrictions in a patriarchal society.

In chapter 5 I analyze the work of Dan Guerrero, the son of the legendary Chicano musician Lalo Guerrero, who brings all of these topics and characters together through his performance ;Gaytino! by inscribing a sixtyfive-year-old queer subject into history. Guerrero's autobiographical performance presents his constant struggle in accepting his subjectivity as a queer Chicano in a country that constantly discriminates against both Chicanos and queers. Chicana queer theory, as formulated by Gloria Anzaldúa and Cherríe Moraga, is essential for expanding the notion of home and in the creation of my concept of "the queer zone of comfort" to contextualize queer Chicanas/Chicanos, who must inhabit a safe space in order to bring all aspects of their subjectivity together to create change from within and for their various communities.

Wild Tongues points to the permanence and contemporaneity of these four characters - the peladita/peladito and the pachuca/pachuco-in the cultural productions of Mexico and the United States. Moreover, it reinscribes and reconnects these figures at a binational level through mostly unknown texts, such as Lalo Guerrero's pachucada songs and La Chata's unpublished skits. These texts offer a critique of the invisibility and the exploitative economic system that working-class Chicana/Chicano and Mexican people experience on both sides of the border. At the core of this book remains my critique of transnational capitalism that continually affects cultural productions on both sides of the border. 
WILD TONGUES 
THIS PAGE INTENTIONALLY LEFT BLANK 